\title{
Incidence of cancer in Bradford Asians
}

\author{
R M Barker, M R Baker
}

\begin{abstract}
Study objective-The aim of the study was to investigate the incidence of cancer in Asians living in Bradford.
\end{abstract}

Design-Cancer registrations were obtained from the Yorkshire Regional Cancer Registry for the six year period 1979-1984. Registrations relating to persons of Asian background were extracted using forenames and surnames. Data were analysed by disease category and age and sex specific incidence rates were calculated. These were compared with expected incidence rates for the non-Asian population and with rates for the Indian subcontinent derived from the Bombay Cancer Registry.

Setting-Data collection was confined to the Bradford Metropolitan District, population 449897 (1981).

Subjects-The Asians studied originated from Pakistan (65\%), India (28\%), Bangladesh (4\%), and East Africa (3\%). The total Asian population of the Bradford Metropolitan District was approximately 45000.

Main results-Over the study period there were 178 Asian cancer registrations. The overall standardised registration ratio was 53.7 for males (100 cases, $95 \%$ confidence interval $43-64$ ), and 43.5 for females ( 78 cases, 95\% CI 34-53). The standardised registration ratios for cancer of the hypopharynx in males and gall bladder in females were significantly raised. There was a particularly low incidence of cancer of the stomach, large bowel, lung, skin, and bladder in males, and of skin, breast, cervix (in situ), and ovary in females. The analyses suggested that lung and breast cancer incidence may be increasing towards the non-Asian level. In situ cancer of cervix in Asians shows no evidence of the high rates found in younger non-Asian age groups.

Conclusions-Lower incidence of many cancers in Asians may be due to lower exposure to major risk factors. Demographic change resulting in increased exposure to these risk factors can be expected to result in an increase in cancer incidence in Asians.

Correspondence to:

Dr Barker at Herefordshire Health Authority, Victoria House, Eign Street, Hereford HR4 OAN,

United Kingdom

Accepted for publication September 1989

Bradford is an industrial city, situated in West Yorkshire, the origins of which stem from the development of the wool and textile industries. During the 1950s, and particularly the 1960 s, considerable immigration of manual semiskilled labour from the Indian subcontinent occurred. With the subsequent decline in the wool and textile industries, a large proportion of these people are now unemployed.

Overall cancer incidence in the Indian subcontinent is thought to be lower ${ }^{1-3}$ than that in the United Kingdom. Migrants are exposed to a new environment containing new risk factors, both known and unknown. The combination of exposure to the general environmental risk factors and the degree of exposure to personally influenced risk factors will determine how rapidly the pattern of cancer in a migrant population will change towards that of the host population. It is only by studies of cancer incidence that this change can be monitored.

It may also be the case that within the low overall incidence of cancer, there are various sites which have high incidence, and health professionals need to be aware of these differences in order to plan preventive measures. Furthermore, descriptive studies of cancer in migrant populations can provide pointers to the possible aetiology of these conditions in both the migrants and the indigenous population. A study was therefore undertaken to determine the incidence of cancer in the Bradford Asian population.

\section{Methods}

In this paper, the term "Asian" will be used to refer to those people who originated in Pakistan, India or Bangladesh and those of Pakistani and Indian descent who originated from East Africa. The origins of the Asian population in Bradford are as follows: $65^{\circ}{ }_{1}$, come from Pakistan (mainly from the Mirpur District), $28^{\circ}$ " from India (Punjab and Gujurat), 4" ${ }^{\prime \prime}$ from Bangladesh (Sylhet) and $3^{\circ}{ }^{\circ}$ from East Africa (origins in Punjab and Gujurat). ${ }^{4}$ The approximate religious composition of the Bradford Asian community is Muslim $70^{\circ}{ }_{0}$, Hindu $15^{\circ}{ }^{\circ}$ and Sikh $15^{\circ}{ }^{\circ}$.

A list of cancer registrations for the Bradford Metropolitan District was obtained from the Yorkshire Regional Cancer Registry for 1979-84 inclusive. Registration data are routinely collected by clerical staff at all hospitals in Yorkshire, from copies of pathology reports and from death certificates where a diagnosis of cancer has been made. Post codes are used to allocate registrations according to District.

Registrations relating to those of Asian 
The Asian population figures are derived from an analysis of the 1981 census carried out by Ballard $^{4}$ at the University of Leeds. No explicit ethnic question was asked in the census and the method used sorted the population by the birthplace of the heads of households in which they lived. There are a few white Britons who were born in what was then part of the "empire", but their numbers will be small. Although this method should give a reasonably accurate figure in this instance, it will become less accurate in the future as increasing numbers of British born second generation Asians leave home and establish households themselves.

The total population of Bradford Metropolitan District in 1981 was 449897 of whom 45100 $(10.02 \%)$ were of Asian origin. This study analyses data from 1979-1984. As the Asian population is growing at a faster rate than the white population, the present Asian population will be slightly greater than that used as the denominator.

The data were analysed by disease category, and age and sex specific incidence rates were calculated for the non-Asian section of the population. The expected number of Asian registrations was then calculated, using these rates and the Bombay Cancer Registry rates. ${ }^{7}$ The Bombay Cancer Registry is the oldest and largest cancer registry in the Indian subcontinent and, although the population of Bombay differs from the Bradford Asian population, the overall incidence rate is unlikely to be radically different and might corroborate evidence of early changes in cancer incidence in the migrant population. The Standardised Registration Ratios (SRR) were also calculated with $95 \%$ confidence limits, using the method described by Liddell. ${ }^{8}$

\section{Results}

There was a total of 178 registrations for Asians from Bradford during 1979-84, 100 for males and 78 for females. Table I shows the Asian registrations and SRRs, calculated using the Bradford non-Asian rates and the Bombay Cancer Registry rates, from all causes by sex and age groups. The number of registrations for both sexes was significantly less than expected when compared with non-Asian rates and slightly more than expected on comparison with the Bombay Cancer Registry rates. However, it is interesting to note that the observed registrations for the

Table I Registrations ( $n$ ) and standardised registration ratios ( $S R R$ ), using non-Asian (NA) rates and Bombay registry rates (BCR), by sex and age group, for Bradford Asians. Figures in parentheses are $95^{\circ}$, confidence intervals

\begin{tabular}{|c|c|c|c|c|c|c|}
\hline \multirow{2}{*}{$\begin{array}{l}\text { Age } \\
\text { group (years) }\end{array}$} & \multicolumn{3}{|c|}{ Males } & \multicolumn{3}{|c|}{ Females } \\
\hline & & SRR (NA) & $\overline{\text { SRR (BCR) }}$ & $\bar{n}$ & SRR (NA) & SRR (BCR) \\
\hline$<20$ & 11 & $\begin{array}{l}111 \cdot 1 \\
(55-199)\end{array}$ & $\begin{array}{l}151 \cdot 5 \\
(76-271)\end{array}$ & 7 & $\begin{array}{l}95 \cdot 6 \\
(38-197)\end{array}$ & $\begin{array}{l}191 \cdot 3 \\
(77-394)\end{array}$ \\
\hline $20-39$ & 8 & $\begin{array}{l}52 \cdot 3 \\
(23-103)\end{array}$ & $\begin{array}{l}100 \cdot 3 \\
(54-197)\end{array}$ & 25 & $\begin{array}{l}34 \cdot 3^{\star} \\
(21-48)\end{array}$ & $\begin{array}{l}210 \cdot 4^{\star} \\
(128-293)\end{array}$ \\
\hline $40-59$ & 57 & $\begin{array}{l}64 \cdot 1^{\star} \\
(47-81)\end{array}$ & $\begin{array}{l}108 \cdot 9 \\
(81-137)\end{array}$ & 28 & $\begin{array}{l}38 \cdot 9 \star \\
(24-53)\end{array}$ & $\begin{array}{c}71 \cdot 4^{\star} \\
(45-98)\end{array}$ \\
\hline $60+$ & 24 & $\begin{array}{c}33 \cdot 2^{\star} \\
(20-46)\end{array}$ & $\begin{array}{l}94 \cdot 1 \\
(56-132)\end{array}$ & 18 & $\begin{array}{l}66 \cdot 5^{\star} \\
(36-97)\end{array}$ & $\begin{array}{l}163.9 \\
(97-259)\end{array}$ \\
\hline All ages & 100 & $\begin{array}{c}53 \cdot 7^{\star} \\
(43-64)\end{array}$ & $\begin{array}{l}107 \cdot 5 \\
(86-129)\end{array}$ & 78 & $\begin{array}{l}43 \cdot 5^{\star} \\
(34-53)\end{array}$ & $\begin{array}{l}118 \cdot 7 \\
(92-145)\end{array}$ \\
\hline
\end{tabular}

* Significant at $95^{\circ}{ }_{0}$ level $^{8}$ under 20 year old age group are close to those expected from the non-Asian rates and considerably higher than those expected from the Bombay Cancer Registry rates.

Table II gives the incidence figures for Asian males and females by individual site. In comparison with non-Asians, there were significantly raised SRRs for the hypopharynx in males and for the gall bladder in females. There were significantly low SRRs compared with nonAsians for stomach, large intestine, lung, skin and bladder in males, and skin, breast, cervix (in situ) and ovary in females.

Table III lists the age and sex standardised (standard world population-developing countries) rates from the Bombay registry, the Ahmedabad registry (situated in Gujurat), the Lahore and the Pershawar registries (closest registries to Mirpur and the Pakistan Punjab) for lung, breast and cervical cancer registrations. ${ }^{79}$ The rates for these cancers for England and Wales are also listed for comparison, but have not been standardised to the above population.

Further analysis of cancer of the trachea, lung and bronchus in males ( 22 cases), and breast ( 15 cases) and in situ cancer of the cervix (seven cases) in females was undertaken and the results presented in figs 1-3.

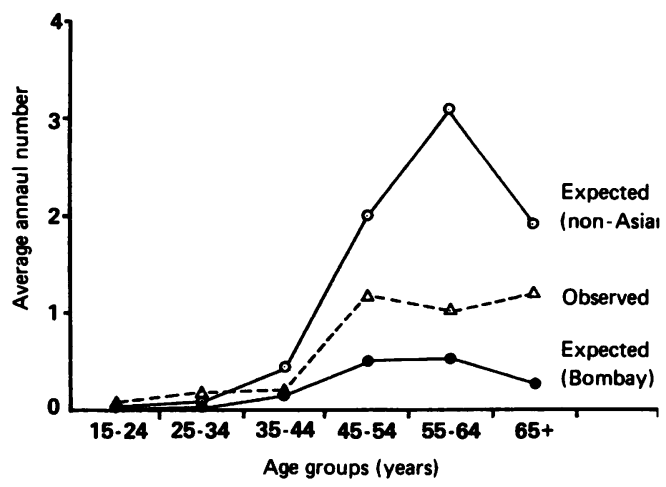

Figure 1 Lung cancer registrations for Asian males, 1979-84, compared with the expected incidence using non-Asian and Bombay Registry rates.

The incidence of lung cancer in Asian males in Bradford appears to lie between that expected in Bombay and that expected in the non-Asian population. For breast cancer, the incidence in Asian females appears to follow that of the nonAsian population in the younger age groups and the Bombay pattern in the older age groups. For in situ cancer of the cervix, it is evident that Asian females from the younger age groups do not display the high incidence of this cancer found among the non-Asian population.

\section{Discussion}

Studies of cancer incidence in Asian populations in this country ${ }^{12}$ are always hampered by small numbers of cases and unreliable denominator populations. The small number of cases is partly due to the low overall incidence of cancer in Asians and the predominantly youthful nature of the Asian population. The size of the Asian population is also difficult to ascertain but it is possible that this problem may be resolved by the inclusion of a question on ethnic identity in the 
Table II Observed and expected incidence, and the standardised registration ratio ( $S R R$ ) of cancers occurring in the Bradford Asian population
Figure 2 Breast cancer registrations for Asian females, 1979-84, compared with the expected incidence using non-Asian and Bombay Registry rates.

\begin{tabular}{|c|c|c|c|c|c|c|c|}
\hline \multirow[b]{2}{*}{ ICD9 code } & \multirow[b]{2}{*}{ Site } & \multicolumn{3}{|c|}{ Males } & \multicolumn{3}{|c|}{ Females } \\
\hline & & \multicolumn{2}{|c|}{ Observed (Exp) } & $\begin{array}{c}\text { SRR } \\
0\end{array}$ & \multicolumn{2}{|c|}{ Observed (Exp) } & $\begin{array}{r}\text { SRR } \\
556\end{array}$ \\
\hline $\begin{array}{l}141 \\
142 \\
144 \\
145 \\
146 \\
147 \\
148\end{array}$ & $\begin{array}{l}\text { Tongue } \\
\text { Salivary glands } \\
\text { Floor of mouth } \\
\text { Other mouth } \\
\text { Oropharynx } \\
\text { Nasopharynx } \\
\text { Hypopharynx }\end{array}$ & $\begin{array}{l}- \\
1 \\
1 \\
2 \\
2 \\
1 \\
3\end{array}$ & $\begin{array}{l}(1.02) \\
(0.90) \\
(0.42) \\
(0.66) \\
(0.72) \\
(0.30) \\
(0.42)\end{array}$ & $\begin{array}{l}0 \\
111 \\
238 \\
303 \\
278 \\
333 \\
714^{\star}\end{array}$ & $\begin{array}{l}1 \\
\bar{z} \\
- \\
\overline{1} \\
\overline{1}\end{array}$ & $\begin{array}{l}(0.18) \\
(0.42) \\
(0.12) \\
(0.24) \\
(0.12) \\
(0.00) \\
(0.18)\end{array}$ & $\begin{array}{r}556 \\
0 \\
0 \\
0 \\
0 \\
0 \\
556\end{array}$ \\
\hline $\begin{array}{l}150 \\
151 \\
153 \\
154 \\
155 \\
156 \\
157\end{array}$ & $\begin{array}{l}\text { Oesophagus } \\
\text { Stomach } \\
\text { Large intestine } \\
\text { Rectum } \\
\text { Liver } \\
\text { Gall bladder } \\
\text { Pancreas }\end{array}$ & $\begin{array}{l}1 \\
4 \\
2 \\
5 \\
-1 \\
4\end{array}$ & $\begin{array}{r}(4 \cdot 14) \\
(10 \cdot 86) \\
(9 \cdot 00) \\
(9 \cdot 72) \\
(1 \cdot 62) \\
(1 \cdot 14) \\
(4 \cdot 92)\end{array}$ & $\begin{array}{l}24 \\
37^{\star} \\
22^{\star} \\
51 \\
0 \\
88 \\
81\end{array}$ & $\begin{array}{l}- \\
3 \\
2 \\
3 \\
1 \\
3 \\
1\end{array}$ & $\begin{array}{l}(0.90) \\
(3.18) \\
(6.36) \\
(3.54) \\
(1.14) \\
(0.30) \\
(1.44)\end{array}$ & $\begin{array}{r}0 \\
94 \\
31 \\
85 \\
88 \\
1000^{\star} \\
69\end{array}$ \\
\hline $\begin{array}{l}161 \\
162 \\
163\end{array}$ & $\begin{array}{l}\text { Larynx } \\
\text { Trachea, lung, bronchus } \\
\text { Pleura }\end{array}$ & $\begin{array}{r}2 \\
22 \\
1\end{array}$ & $\begin{array}{r}(3.66) \\
(44.52) \\
(0.96)\end{array}$ & $\begin{array}{l}55 \\
49 * \\
104\end{array}$ & $\overline{4}$ & $\begin{array}{l}(0.54) \\
(8.52) \\
(0.30)\end{array}$ & $\begin{array}{r}0 \\
47 \\
0\end{array}$ \\
\hline $\begin{array}{l}170 \\
171 \\
173\end{array}$ & $\begin{array}{l}\text { Bone } \\
\text { Connective tissue } \\
\text { Skin }\end{array}$ & $\frac{1}{3}$ & $\begin{array}{r}(2.34) \\
(1.32) \\
(26.58)\end{array}$ & $\begin{array}{c}43 \\
0 \\
11^{\star}\end{array}$ & $\begin{array}{l}2 \\
1 \\
3\end{array}$ & $\begin{array}{r}(1 \cdot 32) \\
(1 \cdot 14) \\
(18 \cdot 18)\end{array}$ & $\begin{array}{c}152 \\
88 \\
17^{\star}\end{array}$ \\
\hline 174 & Breast & - & - & - & 15 & (33.96) & $44^{\star}$ \\
\hline $\begin{array}{l}233 \cdot 1 \\
180 \\
181 \\
182 \\
183 \\
185 \\
186 \\
188 \\
189\end{array}$ & $\begin{array}{l}\text { Cervix, in situ } \\
\text { Cervix, invasive } \\
\text { Placenta } \\
\text { Body of uterus } \\
\text { Ovary } \\
\text { Prostate } \\
\text { Testis } \\
\text { Bladder } \\
\text { Other urinary }\end{array}$ & $\begin{array}{l}- \\
\overline{-} \\
\overline{-} \\
\overline{3} \\
1 \\
5 \\
4\end{array}$ & $\begin{array}{c}- \\
- \\
- \\
- \\
- \\
(8 \cdot 46) \\
(5 \cdot 34) \\
(12 \cdot 18) \\
(4 \cdot 08)\end{array}$ & $\begin{array}{l}- \\
- \\
- \\
- \\
\overline{35} \\
19 \\
41^{\star} \\
98\end{array}$ & $\begin{array}{l}7 \\
4 \\
3 \\
1 \\
1 \\
- \\
- \\
- \\
-\end{array}$ & $\begin{array}{c}(54 \cdot 66) \\
(10 \cdot 26) \\
(1.02) \\
(4 \cdot 02) \\
(6 \cdot 84) \\
- \\
- \\
(2 \cdot 22) \\
(1 \cdot 44)\end{array}$ & $\begin{array}{c}13^{\star} \\
39 \\
294 \\
25 \\
15^{\star} \\
- \\
\overline{0} \\
0\end{array}$ \\
\hline $\begin{array}{l}191 \\
192 \\
193 \\
194 \\
140-208\end{array}$ & $\begin{array}{l}\text { Brain } \\
\text { Nervous system } \\
\text { Thyroid } \\
\text { Other endocrine } \\
\text { Other }\end{array}$ & $\begin{array}{l}7 \\
2 \\
1 \\
3 \\
1\end{array}$ & $\begin{array}{l}(7.02) \\
(0.72) \\
(0.66) \\
(0.72) \\
(0.48)\end{array}$ & $\begin{array}{l}100 \\
278 \\
152 \\
417 \\
208\end{array}$ & $\begin{array}{l}1 \\
2 \\
3 \\
\overline{1}\end{array}$ & $\begin{array}{l}(3.24) \\
(0.78) \\
(1.14) \\
(1.20) \\
(0.78)\end{array}$ & $\begin{array}{r}31 \\
256 \\
263 \\
0 \\
128\end{array}$ \\
\hline $\begin{array}{l}200 \\
201 \\
202 \\
203\end{array}$ & $\begin{array}{l}\text { Ret/lymphosarcoma } \\
\text { Hodgkins } \\
\text { Other lymphoma } \\
\text { Myeloma }\end{array}$ & $\begin{array}{l}1 \\
4 \\
3 \\
1\end{array}$ & $\begin{array}{l}(2 \cdot 76) \\
(4 \cdot 44) \\
(2 \cdot 46) \\
(1 \cdot 62)\end{array}$ & $\begin{array}{r}36 \\
90 \\
122 \\
62\end{array}$ & $\begin{array}{l}1 \\
2 \\
1 \\
2\end{array}$ & $\begin{array}{l}(0.42) \\
(1.68) \\
(0.90) \\
(0.78)\end{array}$ & $\begin{array}{l}238 \\
119 \\
111 \\
256\end{array}$ \\
\hline \multirow[t]{3}{*}{204} & $\begin{array}{l}\text { Lymphatic leukaemia } \\
\text { Myeloid leukaemia }\end{array}$ & $\begin{array}{l}4 \\
2\end{array}$ & $\begin{array}{l}(3 \cdot 72) \\
(2 \cdot 34)\end{array}$ & $\begin{array}{r}108 \\
85\end{array}$ & $\begin{array}{l}2 \\
3\end{array}$ & $\begin{array}{l}(1 \cdot 80) \\
(2 \cdot 22)\end{array}$ & $\begin{array}{l}111 \\
135\end{array}$ \\
\hline & Uncertain & 2 & & & 3 & & \\
\hline & Total & 100 & & & 78 & & \\
\hline
\end{tabular}

* Significant at $95^{\circ}{ }_{0}$ level $^{8}$

1991 census. These factors cause difficulty in the interpretation of the data and the findings need to be considered in the context of the other studies carried out in this area.

Our data show that there is a particularly low overall rate of cancer in the Asian population in both males and females when compared with the non-Asian rates, which is in accordance with other studies. ${ }^{1310}$ The lack of a significant difference from the Bombay Cancer Registry rates would support the view that the incidence of cancer in the Asian population has not yet changed to any great degree from that of their home continent.
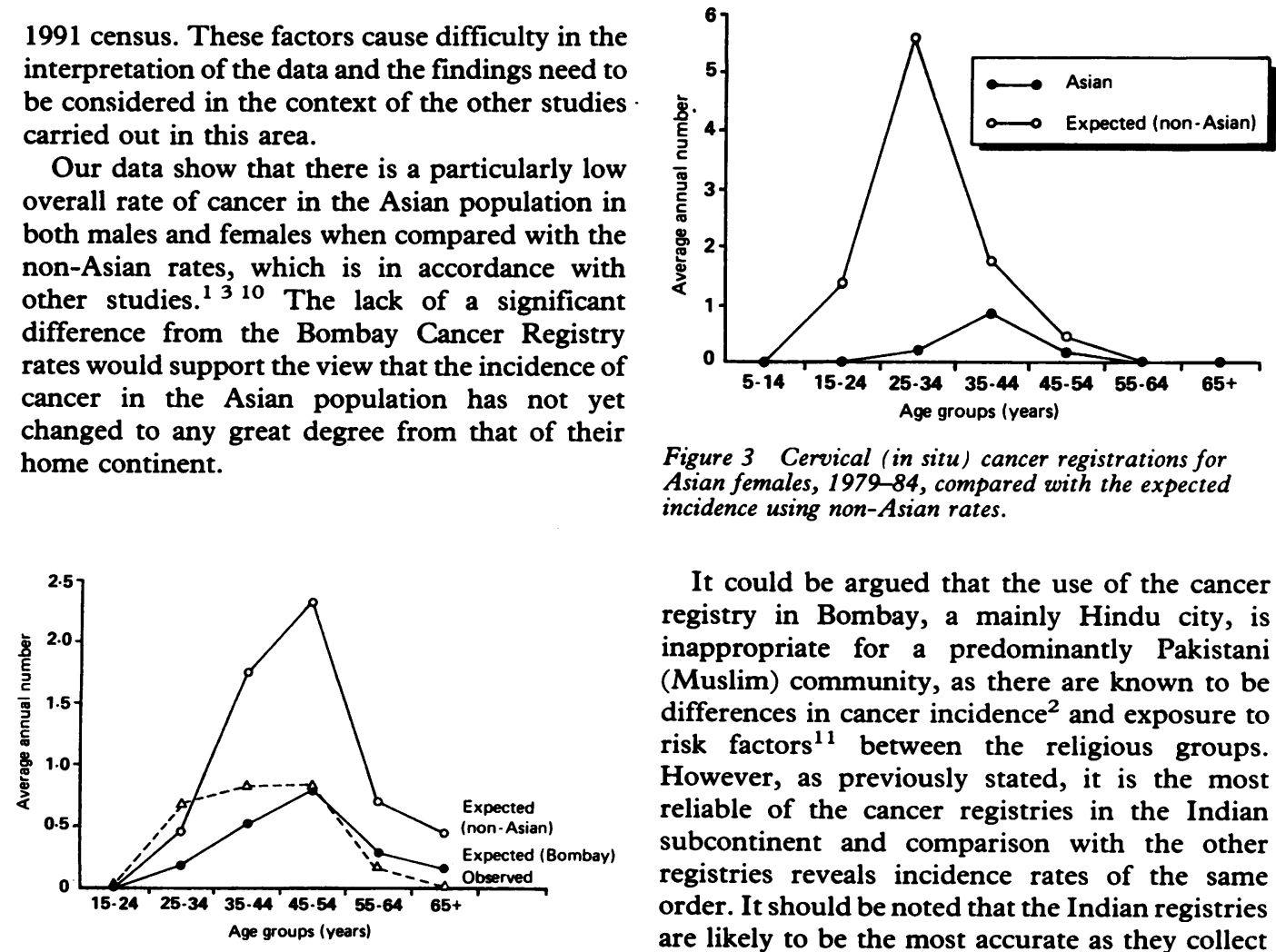

Figure 3 Cervical (in situ) cancer registrations for Asian females, 1979-84, compared with the expected incidence using non-Asian rates.

It could be argued that the use of the cancer registry in Bombay, a mainly Hindu city, is inappropriate for a predominantly Pakistani (Muslim) community, as there are known to be differences in cancer incidence ${ }^{2}$ and exposure to risk factors ${ }^{11}$ between the religious groups. However, as previously stated, it is the most reliable of the cancer registries in the Indian subcontinent and comparison with the other registries reveals incidence rates of the same order. It should be noted that the Indian registries are likely to be the most accurate as they collect 
Table III Comparison of incidence rates per 100000 for selected cancers from different cancer registries

\begin{tabular}{|c|c|c|c|c|c|}
\hline \multirow[b]{2}{*}{ Country } & \multirow[b]{2}{*}{ Registry } & \multicolumn{4}{|l|}{ Cancer } \\
\hline & & Lung (males) & Breast & Cervix & All sites \\
\hline \multirow[t]{2}{*}{ India } & $\begin{array}{l}\text { Bombay } \\
(1973-75)\end{array}$ & $14 \cdot 2$ & $21 \cdot 2$ & $23 \cdot 2$ & M 143.3 \\
\hline & $\begin{array}{c}\text { Ahmedabad } \\
(1978-81)\end{array}$ & $17 \cdot 6$ & $18 \cdot 8$ & $26 \cdot 1$ & $\begin{array}{l}M \quad 137.5 \\
\text { F } 101.2\end{array}$ \\
\hline \multirow[t]{2}{*}{ Pakistan } & $\begin{array}{l}\text { Lahore } \\
\quad(1979-83)\end{array}$ & 4.9 & 23.5 & $8 \cdot 6$ & $\begin{array}{lr}M & 48.2 \\
\text { F } & 71.0\end{array}$ \\
\hline & $\begin{array}{l}\text { Peshawar } \\
\quad(1979-81)\end{array}$ & $5 \cdot 3$ & $10 \cdot 1$ & $3 \cdot 4$ & $\begin{array}{ll}M & 52 \cdot 7 \\
\text { F } & 47.3\end{array}$ \\
\hline England (1978) & & 112.5 & 84.9 & $15 \cdot 4$ & $\begin{array}{l}\text { M } 400 \cdot 3 \\
\text { F } 368 \cdot 1\end{array}$ \\
\hline
\end{tabular}

their data from many sources. The Pakistani registries collect their data from radiotherapy departments and will therefore considerably underestimate and distort the true incidence.

The fact that the youngest age group does not show any significant difference in cancer incidence could be due to the small numbers but is more likely to be due to the fact that this age group will be less affected by environmental and behavioural influences (eight out of 11 males and six out of seven females were 10 years and under).

The high incidence of cancer of the hypopharynx in males is not unexpected. Cancer of the mouth and pharynx are known to have a high inidence in the subcontinent and, apart from the established risk factors of smoking and heavy alcohol consumption, the practice of chewing betel has frequently been implicated, as has the consumption of highly spiced food. The Bradford Asians do not come from areas that traditionally chew betel and although the incidence is much higher than the non-Asians, it is approximately half that in Bombay. Betel chewing has also been linked with a high incidence of oesophageal cancer, ${ }^{12} 13$ a cancer rare in Bradford Asians but common in the Asian community in Leicester. ${ }^{1}$

The high incidence of cancer of the gall bladder is an unexpected finding. Although only three cases were recorded, this still represents a tenfold excess. There is known to be a relationship between the presence of gall stones and the development of cancer but it is not known if the former is particularly high in the Asian community.

Our data on lung and breast cancer incidence show an increase in the younger age groups which may represent early environmental effects on the migrant population. The incidence of lung cancer is known to be much lower in the Indian subcontinent than in the West but the incidence among males is higher. In one study in Chandigarh, ${ }^{14}$ the male:female ratio was $5 \cdot 2: 1$ which compares with $5.5: 1$ in the Bradford Asians, 4.6:1 in Bombay (1975), 3.3:1 in England and Wales (1978), and $2 \cdot 7: 1$ for the Bradford non-Asians. This supports data, discussed below, showing that the practice of smoking among Asian women is not common.

There are no data available from the Indian subcontinent on the incidence of in situ cancer of the cervix. Information on invasive cervical cancer shows a high incidence in the Asian countries overall. ${ }^{79}$ This is reflected in the studies in Leicester ${ }^{1}$ (predominantly Hindu) and in Glasgow $^{10}$ (predominantly Muslim), where incidence rates for invasive cervical cancer were found to be higher than in the non-Asian population. These findings are contradicted by Marmot's study ${ }^{3}$ on immigrant mortality which revealed a proportional mortality ratio of 69 for immigrants from the Indian subcontinent of Asian (as opposed to British) origin.

However, in Bradford, the incidence of in situ and invasive cervical cancer in Asians is considerably lower than in the non-Asian population. There is known to be a low uptake of cervical screening services among the Asian community in Leicester ${ }^{15}$ and there is no reason to believe that Bradford is different, but it is unlikely to explain the difference fully. Furthermore, if this were the case, an increase in the incidence of invasive cancer would be expected and this has not been seen. It is evident that further work needs to be carried out in this area to explain these disparate findings.

The other cancers found to have a significantly low incidence are in accordance with the findings of Donaldson and Clayton in Leicester and the Bombay Registry rates. 17

It is interesting that the common western cancers are also the common Asian cancers, but at a lower incidence. Is this the result of similar exposure to risk factors but by a smaller proportion of the population or is there a lower overall exposure to risk factors? Three common risk factors known to be associated with the development of cancer (ie, smoking, alcohol and diet) will have a different prevalence among the Asian community. Smoking and alcohol consumption among Asians were found to be much less prevalent than in their white counterparts in an analysis of the General Household Survey. ${ }^{16}$ Ahmad, ${ }^{11}$ in a study of General Practice attenders in Bradford, found that $42 \%$ of Pakistani and $28 \%$ of Indian men smoked compared with $44 \%$ of white males. Asian women did not smoke. These figures would support the findings from the General Household Survey.

Alcohol should not be in very widespread use due to its avoidance by the Muslim community. $\mathrm{Ahmad}^{11}$ found that whereas $70 \%$ and $78 \%$ of white males and females admitted to regular alcohol intake, the respective figures for Pakistanis were $3 \%$ and $4 \%$ and for Indians, $48^{\circ}$ o and $7 \%$. This might be an underestimate for the Pakistanis due to a reluctance to admit to a practice that is prohibited by their religion.

There is evidence that Asians have changed their infant feeding patterns ${ }^{17} 18$ towards those of the adopted country, but there is little research on adult dietary changes. It is reasonable to assume 
that the second generation Asians will have incorporated many features of the local diet into their own. It thus appears that at least part of the reduced incidence of cancer could be explained by the lower exposure to the major risk factors. It is likely that both the incidence and the numbers of cancer cases in Asians will increase due to increased exposure to risk factors and demographic changes, especially in the second generation Asian popualtion. It is important that the present low incidence of cancer in the Asian population is not used as justification for lack of effort in carrying the health promotion messages into this community.

CONCLUSION

Studies of this kind are, by their nature, full of imponderables but do help in the identification of possible health risks/needs and as pointers to areas of future epidemiological investigation. Ideally, this study should be repeated on a regular basis to identify trends, but it will become increasingly difficult to establish a population base for those of Asian origin as the two communities become more integrated.

We would like to thank Waqar Ahmad and Antony Franks for their comments during the preparation of this paper and Mrs M Darby of the Yorkshire Regional Cancer Registry for her help in providing the data.

1 Donaldson LJ, Clayton DG. Occurrence of cancer in Asians and non-Asians. $\mathcal{J}$ Epidemiol Community Health 1984; 38: 203-7.

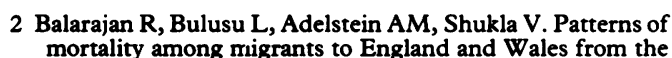
Indian subcontinent. $\mathrm{Br}$ Med f 1984; 289: 1185-7.

3 Marmot MG, Adeistein AM, Bulusu L. Immigrant mortality in England and Wales 1970-78. Studies on Medical and Population Subjects No 47. London: Her Majesty's Stationery Office, 1984.

4 Ballard R. The ethnic minorities in Bradford: an analysis of the 1981 Census. Leeds: Applied Anthropology Group, Department of Psychology, University of Leeds, 1984.

5 Donaldson LJ, Taylor JB. Patterns of Asian and non-Asian morbidity in hospitals. $\mathrm{Br}$ Med $\mathcal{F} 1983$; 286: 949-51

6 Sillitoe K. Ethnic origin: the search for a question. Popul Trends 1978; 13: 25-30.

7 Bombay Cancer Registry. Cancer incidence in five continents, Vol 4 (IARC Scientific Publications No 42). Lyon: International Agency for Research in Cancer, 1982.

8 Liddell FDK. Simple exact analysis of the standardised mortality ratio. $\mathcal{F}$ Epidemiol Community Health 1984; 38 : 85-8.

9 Parkin DM. Cancer occurrence in developing countries. IARC Scientific Publications No 75. Lyon: International Agency for Research in Cancer, 1986.

10 Matheson LM, Dunnigan MG, Hole D, Gillis CR. Incidence of colo-rectal, breast and lung cancer in a Scottish Asian population. Health Bull (Edinb) 1985; 43: 245-9.

11 Ahmad WIU, Kernohan EEM, Baker MR. Alcohol and cigarette consumption among white and Asian general practice patients. Health Educ $f$ 1988; 47: 128-9.

12 Schonland $M$, Bradshaw E. Upper alimentary tract cancer in Natal Indians with special reference to the betel-chewing habit. Br f Cancer 1969; 23; 670-82.

13 Stephen SJ, Uragoda CG. Some observations on oesophageal carcinoma in Ceylon, including its relationship to betel chewing. Br $\mathcal{F}$ Cancer 1970; 24: 11-15.

14 Jindal SK, Malik SK, Dhand R, Gujral JS, Malik AK, Datta BN. Bronchogenic carcinoma in Northern India. Thorax 1982; 37: 343-7.

15 MacAvoy BR. Contraceptive services and cervical cytology. Health Trends 1988; 20: 14-17.

16 Balarajan R, Yuen P. British smoking and drinking habits: variations by country of birth. Community Med 1986; 8: variation.

17 Qureshi B, Morgan JB, Kimber AC, et al. Feeding practices and birth weights of infants in Southall, Middlesex. $f R$ Soc Health 1988; 108: 77-80.

18 Goel M, House F, Shanks RA. Infant feeding practices among immigrants in Glasgow. Br Med $\mathcal{F} 1978 ; 2$ : 1181-3. 